\title{
THE IMPACT OF DOMINANT IDEOLOGY ON FRONT COVERS OF TRANSLATION OF CHILDREN'S LITERATURE IN IRAN \\ Bita Naghmeh-Abbaspour
}

\author{
School of Languages, Literacies, and Translation, UniversitiSains Malaysia (USM), Penang, Malaysia.
} Email: bitana@usm.my

Article History: Received on $23^{\text {rd }}$ December 2019, Revised on $14^{\text {th }}$ April 2020, Published on $26^{\text {th }}$ May 2020

\begin{abstract}
Purpose of the study: The present research aims to explore the impact of the dominant ideological values on the front covers (as a form of paratexts) of translations of children's literature in Iran. Moreover, the study is going to discuss the effect of such ideological manipulation on the children's perspective about the world as well as their own identity.

Methodology: Based on the Foucauldian sense of discourse, which considers any piece of knowledge, either textual or visual, as discourse, the study employs discourse analysis (DA) as its theoretical and analytical framework. Accordingly, the collected data of this study consist of front covers, are understood as discourse, and each one is analyzed carefully with a focus on the impact of ideological manipulation on paratextual material of Persian translations of children's literature.

Main Finding: The findings revealed the supreme role of ideological constraints in the manipulation of front covers of translations of children's literature in Iran.

Application of the study: The current study contributes to the existing body of knowledge on the ideological manipulation of translation of children's literature at the paratextual level in particular.

Novelty/Originality of this study: With respect to the marginal position of translation of children's literature in the Iranian literary polysystem, little effort has been made in this area, and ideological studies of this genre in Iran, in particular. Therefore to fill this void, the current study attempts to examine the impact of ideological constraints of Iranian society on the translation of children's literature.
\end{abstract}

Keywords: Translation of Children's Literature, Paratextuality, Dominant Ideology, Discourse Analysis, Children's Literature.

\section{INTRODUCTION}

For children who have little knowledge about the world, translation is a platform to understand other cultures and respect the differences. However, at the same time, following the ideological values of the target society, the new concepts and ideas of the source culture are generally filtered in children's books. Due to children's limited knowledge, they often are not able to identify the ideological manipulation of the source text in the translation they are exposed to (Kaniklidou \& House, 2018). Moreover, based on the didactic nature of children's literature, "translators, editors and publishers feel at liberty to change original texts to produce imagined effects" (ibid, p. 2). Yet as Oittinen (2002) indicated, translation as a form of rewriting continuously deals with ideology and power concerns. These facts lead to massive filtering in the translation of children's literature that creates an imaginary and unreal perspective of other cultures for unexperienced children who trust translated texts and open their hearts to their influences. Besides, ideological constraints of the target society can affect not only a translated text but also its paratexts (i.e., cover, title, preface, note, etc.). The traditional studies of translation considered the paratexts as a peripheral decorative entity since it merely focused on the textual level of the translation. However, after Genette's monumental discussions on the concept of Paratexts and paratexuality, translation scholars noticed that in the ideological studies of translation, "everything in a book is of importance, every detail carries meaning, all of which are available for translation" (Oittinen, 2004, p. 173). As Pantaleo (2017) highlighted, paratexts consist of every additional information around the text, which purposefully was laid there to mark the text heavily. In contemporary studies of translation, numerous scholars explored the concept of paratextuality in translation, such as Alvstad (2012), Rovira-Esteva (2016), Neveu (2017), Batchelor (2018) and Luo and Zhang (2018) to name a few. However, Rita Oittinen $(2014 ; 2004 ; 2002)$ is one of the well-noted scholars in the translation of children's literature whose studies on the in-text images of translated children's picture books, help the current research in terms of understanding the visual components of the front covers. Although each of the above-noted studies is remarkable on their own nature, to the best of our knowledge, little effort has been made to examine the ideological manipulation of the front covers of translations of children's literature and based on the dominant ideological values of the target society in particular. Moreover, as Kaniklidou and House (2018) highlighted, respecting the variety of characteristics of discourse in the translation of children's literature, conducting researches in different contexts can contribute to the body of knowledge in this domain. Based on the marginal position of translation of children's literature in the Iranian literary polysystem, little effort has been made in this area, and ideological studies of this genre in Iran, in particular. Therefore to fill this void, the current study attempts to examine the impact of ideological constraints of Iranian society on the translation of children's literature. The present research also perceives that the manipulated front covers convey particular ideological messages that may have an impact on the potential child readers. In this regard, based on the findings of the study, it discusses how the ideological manipulation of front covers by reinforcing a specific ideology 
tries to shape a particular perception about the word in the mind of children as the potential receivers of the translated texts.

\section{LITERATURE REVIEW}

Traditional studies of translation hardly considered children's literature as a serious field of practice and study. In 1982 , Katerina Reiss realized with surprise, that although for centuries scholars discuss for different concerns of theory and practice of translation as a complicated phenomenon, they scarcely said anything regarding the translation of children's literature. To Reiss, the problems of translation of children's literature were a real concern; she tried to address it in the context of her text typology. Reiss specified three factors that justify why the translation of children's literature requires a particular kind of study, namely, 1) the asymmetry that governs throughout the whole process of translation for children, which in it, adults translate the texts which are written by adults for children. 2) The controlling agencies that exert pressure on the translator in terms of observing ideological norms as well as educational principles. 3) the limited knowledge of children and young people regarding the world, other cultures and experience of life (as cited in NaghmehAbbaspour, 2013).

Zohar Shavit (2015) was one of the most primitive scholars who in her seminal work, discussed the nature of the translation of children's literature and tried to highlight the reasons that it occupies a peripheral position in the literary polysystem. She believed that due to the peripheral position of translation of children's literature in the literary polysystem, the translators of such texts accredited themselves to manipulate the text with great liberties. To Shavit (2015), translators allow themselves to manipulate the source texts in numerous ways, as long as they consider the following critical assumptions as of the fundamentals of translation of children's literature: 1) adapting the text in a frame that in the target society is considered as appropriate for children.; and 2) adapting the language, plot, and characters of the text, based on children's level of reading ability and comprehension believed that the noted assumptions together create the image of children's literature, yet based on the crucial didactic role of children's literature, the first assumption is the dominant one. Although she noted the necessity of adjustment of the text based on what the target society considers appropriate for children, Shavit just limited her study to the term "appropriation" as a general didactic concept and did not refer to the ideological constraints of the target society. When in 1998, the concept of the cultural turn of translation was introduced by, they bring forth a critical aspect of translation, which was ignored for centuries. Perhaps among different genres of literary translation, children's literature suffers more from denying the cultural and ideological issues of translation, since due to children's lack of experience about the world and other cultures, translation was one of the main sources for the children to understand the cultural differences. However, the emergence of the seminal works like: Ritta Oittinene's Translating for Children (2000); Gillian Lathey' s Translation of Children's Literature (2006); as well as to name a few, in the early years of the twenty-first century indicates that translation of children's literature is left the peripheral position of literary polysystem and is entering into the light.

In spite of the remarkable efforts of scholars like RittaOitteinen in the translation of picture books (Oittinen 2014; 2004; 2000), little effort has made in terms of analyzing the other paratextual material of the translation of children's literature. He studied the relationship of the book cover and the text as a form of intersemiotic translation, and the analysis of his study revealed that not only the cultural assumptions of the illustrators but also those of the other agents like authors, publishers, and even readers were included in the process of creation of front covers. Although Sonzogni's (2011) outstanding work studied the front covers in detail, the focus of his study was on the creation of the covers from the text in an intersemiotic process, not translating paratextual material of the original front covers into the target language. Pereira (2008) is one of the other scholars that some aspects of his seminal study on the translation of book illustrations inspired the current research. Pereira's (2008) seminal work examined the process of translating book illustrations, as authorial paratexts, however, his study did not focus on children's literature, and merely explored the way that illustrations can narrate the story differently by adapting a certain ideology or artistic trends.

Although there is no arguing against the importance of translation of a text in the communication of diverse cultures, it should be considered that texts do not exist without the Paratexts. Indeed "the paratext is what enables a text to become a book and be offered as such to its readers and more generally to the public" (Batchelor, 2018). Considering texts as cultural products that their existence is tightly depended on the readers, they need to be appealing to their potential readers. In this process, the paratexts can provide the best showcase, that either persuade the reader to buy it or leave it aside. Genette (1997) made a distinction between two kinds of 'authorial' and 'editorial' paratexts. The authorial Paratexts are the paratextual material like prefaces, notes, and chapter titles which the author produces them, whereas the editorial paratexts are the paratextual material such as the design of book cover, book title, the layout or number of copies printed, and etc. are managed by the editor or the publisher. Since the authorial paratexts are traditionally considered as part of the source text, usually, they will be translated (regardless of what changes the publisher makes later), whereas the translator typically does not see the editorial paratexts as his/her responsibility (№rd, 2012). Furthermore, based on the proximity or distance of the paratexts to the main text, paratextual material can be divided into two parts of 'peritexts' which include elements such as titles, prefaces, notes as well as the title of chapters which are closely attached to the text, and 'epitexts' which in contrast are parted from the text and provide information about it. Epitexts consist of elements like interviews, reviews, publicity announcements (ibid). The present study limited itself in exploring the front covers as the editorial paratexts, which are also located in the category of the peritexts. Regarding the 
nature of peritexts that are attached to the original text, in the process of translation, they need to be transferred into the target context as well. Oittinen (2014), by emphasizing the crucial role of paratexts in translation, stated that paratextual material predominantly provides valuable background material for the translated text and grant the readers a broader perspective of the translation in question. In the same line, Tymoczko (2014) stated that paratextual analysis is a key factor in investigating the implicit ideological interference of translator; she admitted that translator can set the translated text in a shell (preface, introduction, notes and alike) which functions like providing a commentary on the translation.

Although one of the most popular sayings about books advises us to 'don't judge a book by its cover', a book and its cover are always tightly bonded in a way that "covers may well change how people read books" (Sonzogni, 2011, p. 13). A book cover as the first paratextual element that the potential readers encounter encourages them to either stepping inside or turning away. "Readers get their first glimpse of how a text is structured and what the main ideas are from the book cover. Right from the start, readers thus establish the first interaction with the text through the cover" (Ghandeharion \& Tekiyeh, 2019, p. 154). Indeed, it provides a visual summary of the source culture, setting, and even the book content. The front cover of books as wrapping a cultural product "exerts a direct influence on the text's promotion and reception, as it offers some significant incentives for potential readers" (ibid). Accordingly and based on this potentiality of front cover, apart from facilitating marketing, it is a great platform for propagating the dominant ideology of a society. The main form of censorship prior to publication is the ideological blockage which generally intervenes when a cultural product is entering the target social context (Wolf, 2002). In the same vein, Alvstad (2010) highlighted that in the translation of children's literature, the "cultural context adaptation, and ideological manipulation" can be considered as the primary aspects which attract censorship. Given this fact that the audiences of source and target texts belong to different cultural and ideological contexts, from one hand, leaving the target text in a foreign context may reduce the naturalness of the text and therefore affect the young readers' response. And from the other hand, if the translation diminishes the source text's cultural and ideological items, it may deviate from one of the ultimate didactic goals of translation of children's literature, which is introducing the young readers to the other nations and cultures. Oittinen (2014) noted that still, the scholars of the field did not reach an accord based on the preferred strategy dealing with the ideological controversies in the translation of children's literature.

\section{METHOD}

In view of the Foucauldian feeling of talk, which thinks about any bit of information, either printed or visual, as talk, the examination utilizes talk investigation (DA) as its hypothetical and logical structure. As needed, the gathered information of this examination comprises of intro pages, are comprehended as talk, and everyone is investigated cautiously with an emphasis on the effect of ideological control on paratextual material of Persian interpretations of kids' writing.

In another word, as indicated earlier, the current study investigates the impact of the ideological values of the target society of the paratextual material (here book front covers) of translations of children's literature in Iran. Also, the study is going to discuss the effect of such ideological manipulation on the world view and identity perception of children as the potential audience. Therefore, following these objectives, to highlight the ideologically rooted deviations, the current research compares and contrasts the original front covers with their Persian counterparts. Ten examples of the original front cover of children's literature and the front cover of their Persian translation are presented here, in which each example is followed with a brief analysis, concentrated on the ideological deviations of the frames. Based on the findings, the study also provides more elaboration on the impact of the implied ideological manipulation on the mindset and identity perception of the target audience, which is an Iranian child. It is essential to mention that the present study limited itself to translations, which have been published in the last decade in Iran.

To explore the ideological manipulation of the paratextual material, the present research needs a reliable theoretical and analytical framework. Therefore, with respect to the association of ideology, manipulation, and discourse, as well as considering the multidisciplinary nature of discourse analysis (DA), the current study employed DA as an underpinning analytical framework. As it mentioned earlier, the present study follows the Foucauldian definition of discourse, which considers the discourse as, any particular sort of knowledge about the world, which can shape the audiences' perspective about the world and the way things are done in it (Ahmad \& Ahmad, 2019). Yet, to Foucault, discourse is not necessarily expressed by language but even conveyed by images, in a "mushy mixture of the articulable and the visible" (Smart, 1994, p. 293). Accordingly, images as special forms of knowledge can simply be considered as discourse (Rose, 2001). Therefore, based on the above, the collected data of this study, front covers, are understood as discourse and are analysed carefully, focusing on the impact of targeting ideological constraints on front covers of Persian translations of children's literature.

\section{RESULTS}

The following section comprises ten examples showing original front covers of children's literature, alongside their counterparts in the Persian language. To highlight the ideological manipulation imposed on each frame, the original front cover and front cover of the Persian translation of the book are compared and contrast. The analysis pertains to each example is explained directly under them. 
Figure 1 is the front cover of a Korean version of Alice's Adventures in Wonderland. The front cover of this version bears different levels of manipulation in translation into the Persian language in two different editions of the book, different levels of ideological manipulation employ. In the first edition of the Persian translation of the book, which was published in 2001, Alice's hair is cut short, and her original short sleeve dress changed into a long-sleeve one. Also, since play cards are strictly banned in Iran, all the play cards' symbols (hear, clubs, diamond, and spade) are removed from the front cover. However, the recent edition of the book, which was published in 2019, has a different cover. In the latest front cover, not only Alice is wearing a long sleeve dress, surprisingly she is wearing a scarf to cover her hear. This deviation, with no doubt, is due to the Islamic ideological constraints of Iran.

Example 1: Alice's Adventures in Wonderland (Carroll, L. 2011)

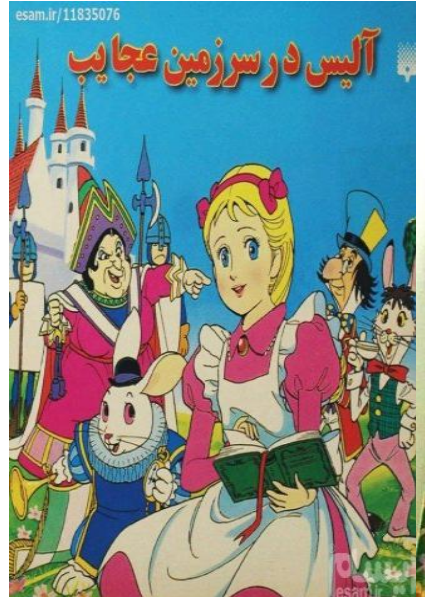

Figure 1

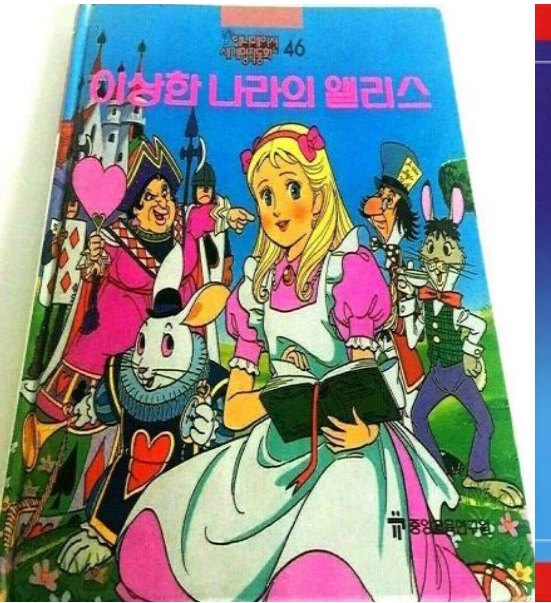

Figure 2

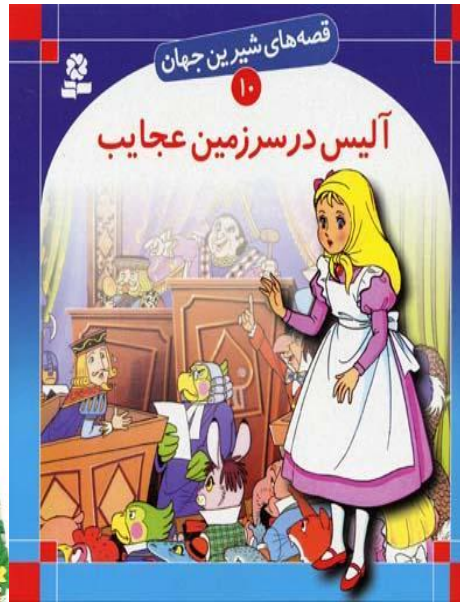

Figure 3

Example 2: Umbrella summer Stevenson, (D. 2009).

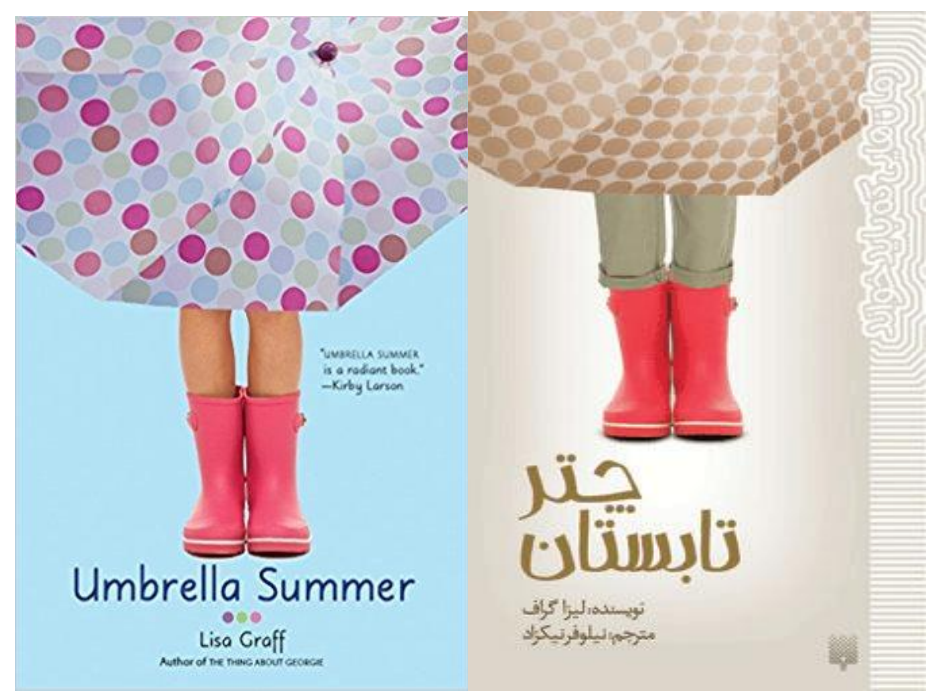

Figure 4

Figure 5

Figure 4, is the front cover of the source text, 'Umbrella Summer,' which illustrated a child standing behind an open pink-purple umbrella. The child's face is not displayed; the picture merely depicted parts of two legs and a pair of pink plastic boots. Based on the prevalent perception of pink color as a gender identifier for females, we can comprehend that the child is a girl. Although referring to the text, we realize that our guess was correct, and this is the figure of the protagonist of the story, Annie Richards.

Figure 5 displays the Persian version of 'Umbrella Summer' front cover. In this picture, the same umbrella (in brown) and pink plastic boots are recognizable, whereas the legs are simply covered by long pants.

Figure 6 presents the cover of 'the higher power of lucky,' illustrated a young girl that wears a long sleeveless red dress. The Persian translation of the book used the very same picture as its front cover, but with a modification in the dress. As Figure 7 indicates, the sleeveless dress changed to a long-sleeve one. Although merely the dress is changed into a long sleeve and the hair is not covered, we still can perceive that the adjustment is implemented considering the Islamic covering rules for females. Perhaps the filtering agencies considered the figure's hand more revealing than her hair. 
Example 3: The Higher Power of Lucky (Patron, S. 2007).

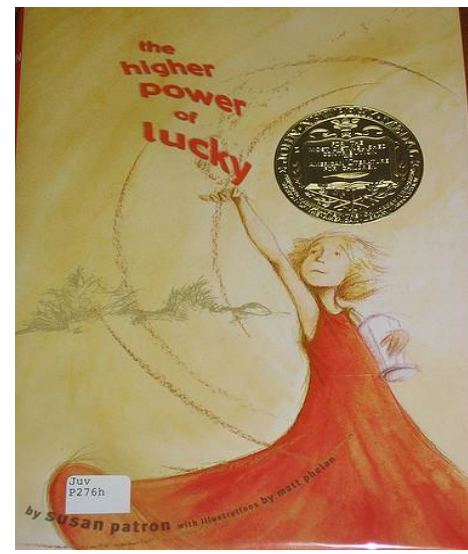

Figure 6

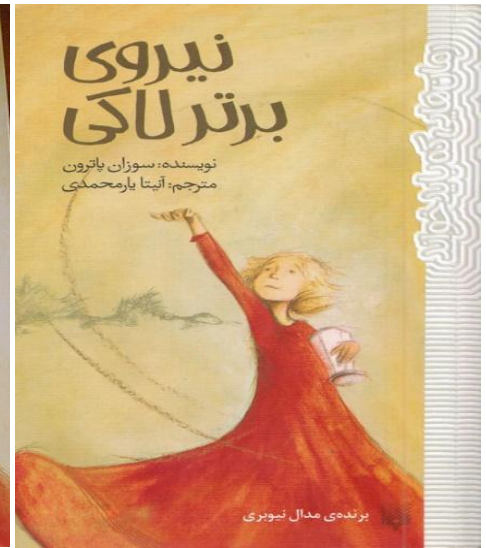

Figure 7

Example 4: Beneath a Meth Moon (Coats, K. 2012)

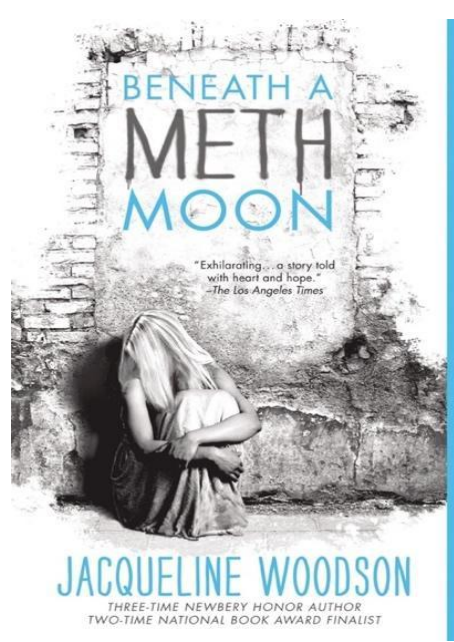

Figure 8

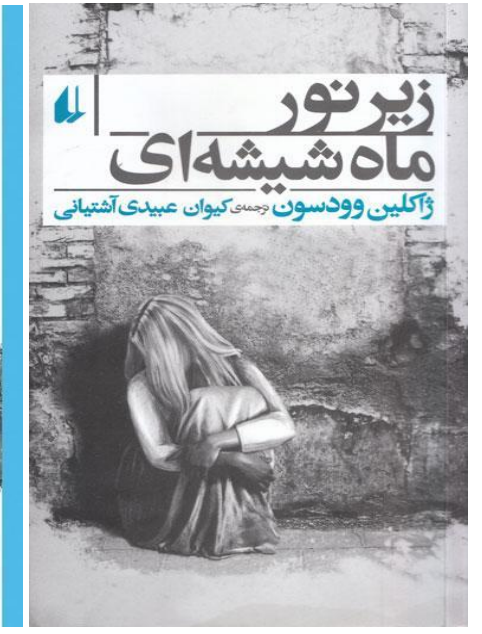

Figure 9

Figure 8 and 9, provide another example of the deviation of a front cover based on the dominant Islamic ideology of Iranian society. Although the Persian translation of the book used the same picture as the original cover, some modifications were applied to make it more congruent with the dominant ideology of the target context. As the comparison of these frames reveals, the sleeveless dress of the female figure in the original front cover (Figure 8), is changed into a long-sleeve one (Figure 9). In this example, exactly like the previous one, merely the hands of the female figure are covered, but her hair is depicted as the original picture.

Example 5: Sottagskind

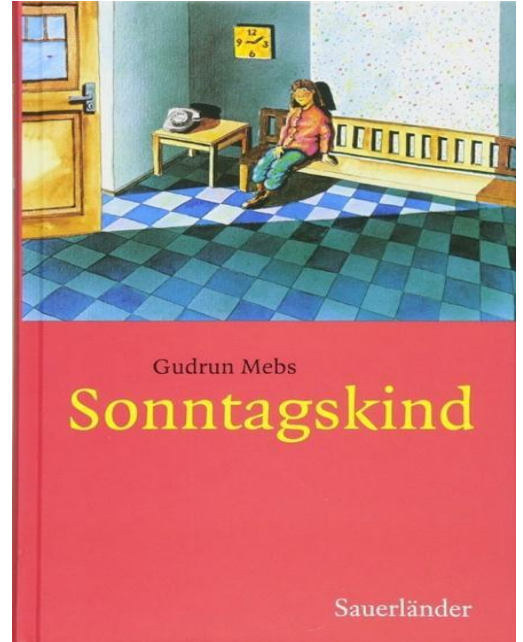

Figure 10

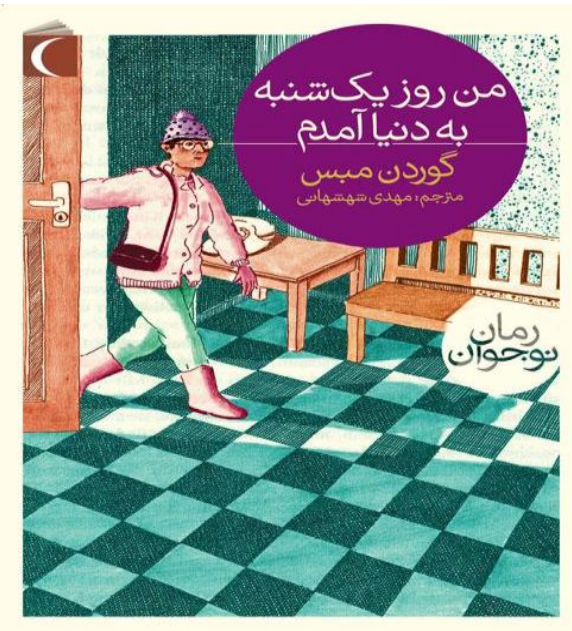

Figure 11 
The original book cover, Figure 10, depicts a girl with shoulder-length hair, sitting in a room. Whereas the book cover of Persian translation, Figure 11, illustrated a girl walking in the same room, wearing the same outfit as the original cover. Yet, a winter hat is added to her clothing that entirely covered the hair. To make the changes seem reasonable, the illustrator replaced the siting girl into a girl entering the room, since usually, when people are indoors, they do not keep their hats on. In this illustration, the hair should be covered by the hat.

Example 6: Igraine the Brave (Bordner, L. 2008)

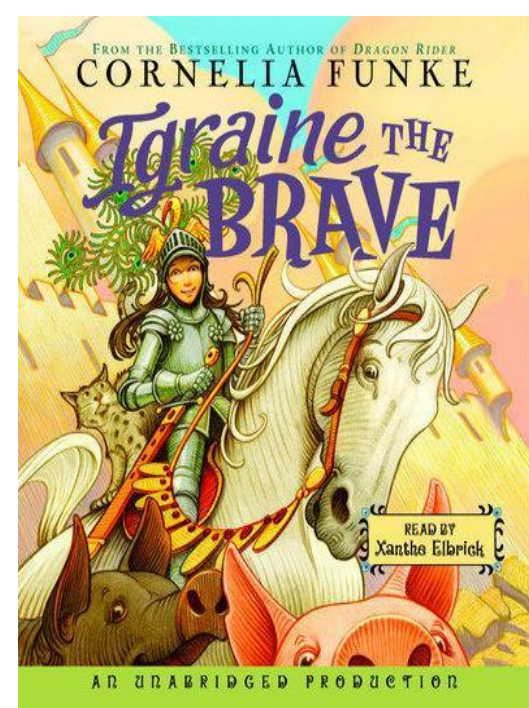

Figure 12

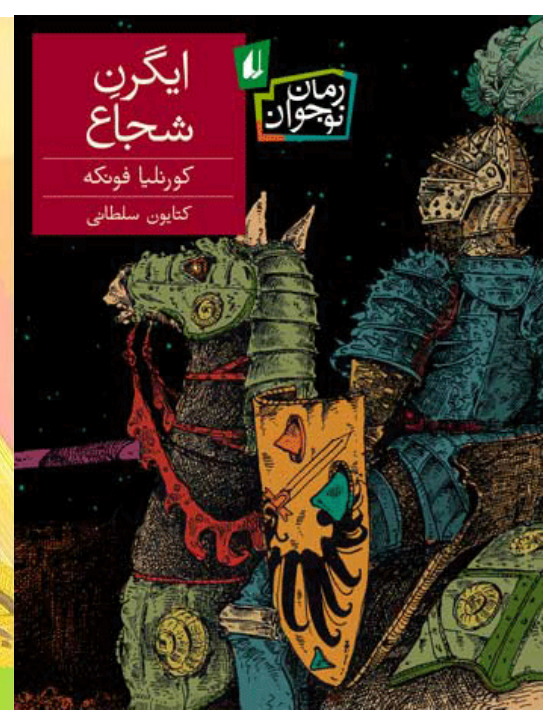

Figure 13

Figure 12 illustrates the female protagonist (Ingrine the brave) wearing an armor and iron helmet while her dark hair is falling out of the helmet, and she is smiling to the audience. Although Igraine is wearing battle clothes, the atmosphere of the cover is soft, colorful, perhaps to highlight the girlish nature of the protagonist. However, in the front cover of the Persian translation of the book, Figure 13, Igraine's face and hair are covered with the helmet, in a way that we cannot perceive that the figure in the picture is either a girl or a boy.

Example 7: Falling Angels (Chevalier, T. 2002)

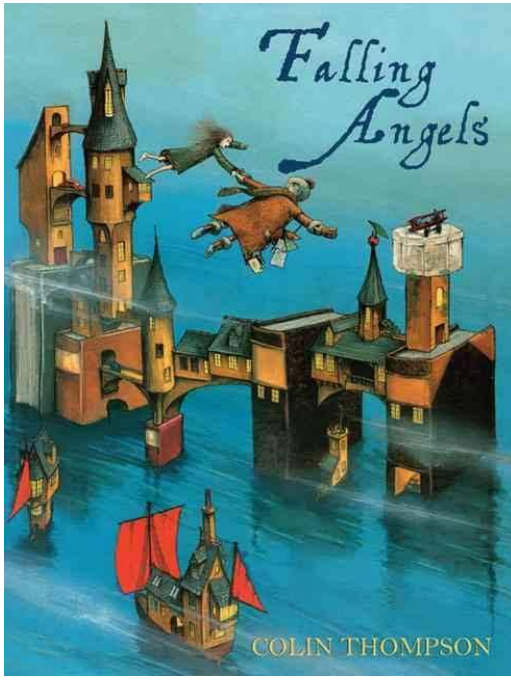

Figure 14

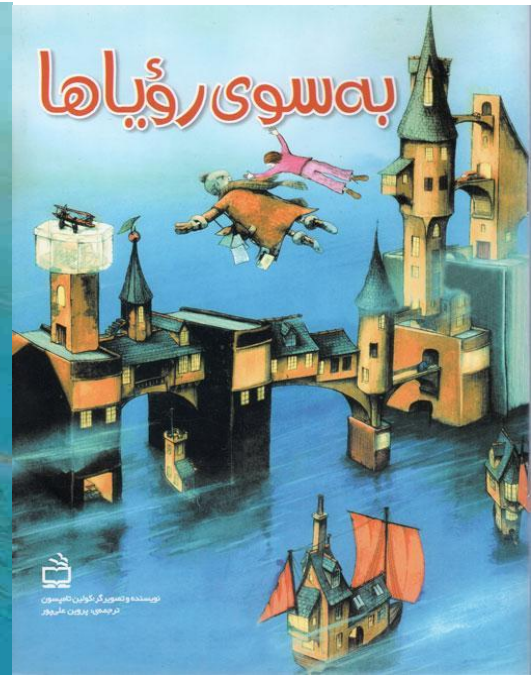

Figure 15

Figure 14 presented the original front cover of "Falling Angels" which in the process of translation into Persian has been changed. As we can see in the original frame, two figures are flying over the sea. Although the figures are relatively in the far distance and we cannot see the faces clearly, yet based on the long hair and the green dress, we can say that one of them is a girl. However, in the front cover of the Persian translation of the book, Figure 15, these vague feminine elements are changed due to the dominant ideological values of the society. The girls' long hair cut short, and the green dress is replaced with a pink shirt and trousers. 
Example 8: Ella Enchanted (Levine, G. C., \&Riegel, E. 1997)

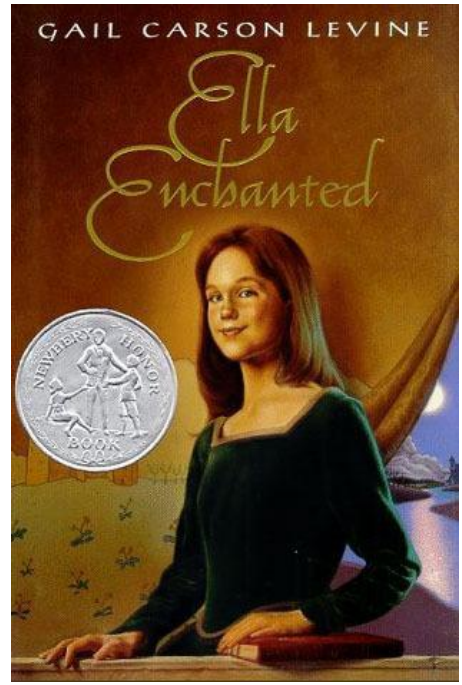

Figure 16

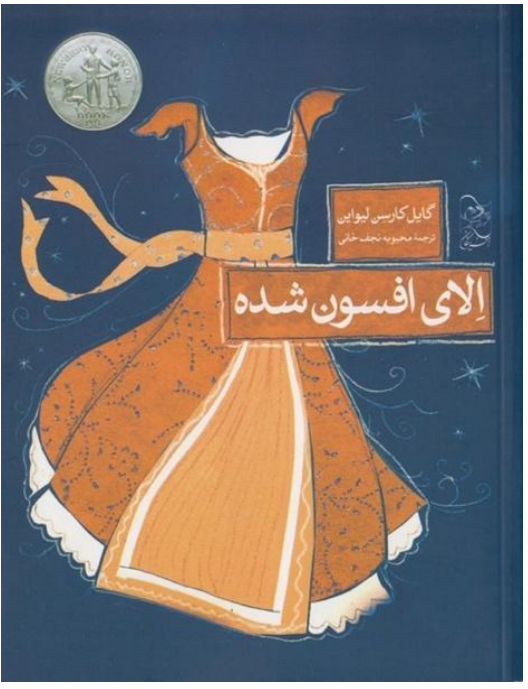

Figure 17

Figures 16 depicted the original front cover of Ella Enchanted, which in it the protagonist, Ella, is illustrated as a teenage girl with long hair wearing a classic Victorian dress. However, on the front cover of the Persian translation, Figure 17, Ella is omitted from the frame, and merely a puffy old fashion dress with apron is floating in the air. So here, instead of covering up Ella or changing her identity, the female protagonist totally omitted from the front cover of translation Persian.

The analysis of the examples reveals some specific facts about translating the par textual data in Iran, following the ideological constraints of the society. The focus of the study was on the impact of the dominant ideological constraints on the translation of front covers of children's literature in Iran. Therefore, the study analyses ten sets of examples to explore the congruency of the original front cover and the front cover of a translated children's literature in Iran. As the analysis revealed, all deviations of the front covers were ideologically rooted. However, the majority of deviations were concentrating on the coving of the female body based on Islamic ideology. In this regard, different strategies were applied, such as adjusting dresses of the female figures, coving up the hair, cutting the hair, and even omitting the female figures from the frame. Therefore, it can be concluded that the majority of the changes on the front covers are focused on female representation. In this process, the feminine side of female characters, such as hair or even their body form, is simply adjusted either by covering them up or representing them in a way that their gender is not visually recognizable. These sorts of strategies are justifiable in terms of nudity or the presence of cultural taboos, and most of the examples discussed in the present study, the deviations seem unnecessary. Excluding the female or fading their presence from the book cover can simply send a message to the child reader that not only affects their understanding about the book and deprives them of knowing the other cultures and religions but also, during the time, can have an extreme impact on their perception about the females in the society. Removing or filtering of females repeatedly and unnecessarily in children's literature of a community fades their presence and pushes them to a peripheral position. This perspective can develop in the mind of children that are the consumers of that literature. To be specific, the noted unnecessary filtering of female figures can create a particular female identity in the mind of Iranian child readers, which definitely will exert its influence in the identity perception and world view of the next generation. In the same vein, Alvstad (2010) highlighted the role of children's literature in next-generation behavior:

“The values and ideas of children's books are of huge cultural relevance precisely because children's books are read by and for children, and such values and ideas are often passed on to future generations. Cultural manipulation and concrete interventions made in relation to racist or sexist elements ... ought to be interpreted in this context. If a given society considers it inappropriate that children use "bad" words, or that" (Alvstad, 2010, p. 26).

\section{CONCLUSION}

In the past few years, scholars have redirected the research path to a new and promising avenue wherein translator's visibility is explored from paratexts rather than from the translations, highlighting the pivotal role and the position of translators as key agents in the translation process (Naghmeh-Abbaspour, Sepora Tengku Mahadi, \& Jamal, 2019). To sum up, the analysis of the examples revealed that the collected paratextual material of translations of children's literature is dramatically manipulated in line with the ideological values of the target social context. As discussed earlier, in different societies based on their ideological constraints, filtering is not an unfamiliar phenomenon, particularly in terms of translation of children's literature and regarding the didactic nature of it. However, from the same educational nature, the primary function of translation of children's literature is introducing the other cultures and nations to children. Therefore, based on this challenging nature of the translation of children's literature, the filtering agencies of 
Iran should revise their filtering standards and allow the new generation to understand the ideological differences and respect them.

The present paper has examined the impact of ideological constrains of Iranian society in the translation of paratextual material, in particular, front covers of translations of children's literature. The findings of the current study contribute to the existing body of knowledge on the ideological manipulation of translation of children's literature at the paratextual level in particular. The study attempts to demonstrate how translations of children's literature in Iran go through ideological manipulation in terms of front covers. To this end, the study discusses the fidelity in translation is not limited to the text, and it should be considered at the paratexts level. Therefore, since employing the unnecessary manipulation of paratextual material such as front covers can threaten the fidelity of the target text, the study suggests the filtering agencies revise their standards based on the nature of the translation of children's literature and grant the children to have a better perspective towards the other cultures and nations.

\section{LIMITATIONS OF THE STUDY}

The aim of this study was to investigate the effect of dominant ideological values on the front covers of translations of children's literature in Iran, while this study can be done on a larger scale for all levels of study and globally.

\section{ACKNOWLEDGMENT}

The author confirms that the data do not contain any conflict of interest.

\section{REFERENCES}

1. Alvstad, C. (2010). Children's literature and translation. Handbook of translation studies, 1, 22-27. https://doi.org/10.1075/hts.1.chi1

2. Alvstad, C. (2012). The strategic moves of paratexts: World literature through Swedish eyes. Translation Studies, 5(1), 78-94. https://doi.org/10.1080/14781700.2012.628817

3. Ahmad, I., \& Ahmad, S. (2019). The Mediation Effect of Strategic Planning on The Relationship between Business Skills and Firm's Performance: Evidence from Medium Enterprises in Punjab, Pakistan. Opcion, 35(24), 746-778.

4. Bassnett, S., \&Lefevere, A. (1998). Constructing cultures: Essays on literary translation (Vol. 11). Multilingual Matters.

5. Batchelor, K. (2018). Translation and paratexts. Routledge. https://doi.org/10.4324/9781351110112

6. Bordner, L. (2008). Igraine the Brave.

7. Carroll, L. (2011). Alice's adventures in wonderland. Broadview Press.

8. Chevalier, T. (2002). Falling Angels: A Novel. Penguin.

9. Coats, K. (2012). Beneath a Meth Moon. Bulletin of the Center for Children's Books, 65(7), 379-380. https://doi.org/10.1353/bcc.2012.0191

10. Even-Zohar, I. (1979). Polysystem theory. Poetics today, 1(1/2), 287-310. https://doi.org/10.2307/1772051

11. Genette, G. (1997). Paratexts: Thresholds of interpretation (Vol. 20). Cambridge University Press.

12. Ghandeharion, A., \&Tekiyeh, M. S. M. (2019). Ideology Behind the Covers of the Bestselling Books in Iran: Female Narrators in War Literature. Frontiers: A Journal of Women Studies, 40(1), 146-175. https://doi.org/10.5250/fronjwomestud.40.1.0146

13. Kaniklidou, T., \& House, J. (2018). Discourse and ideology in translated children's literature: a comparative study. Perspectives, 26(2), 232-245. https://doi.org/10.1080/0907676X.2017.1359324

14. Lathey, G. (Ed.). (2006). the translation of children's literature: A reader. Multilingual matters.

15. Levine, G. C., \&Riegel, E. (1997). Ella enchanted. HarperCollinsPublishers.

16. Luo, T., \& Zhang, M. (2018). Reconstructing cultural identity via paratexts: A case study on Lionel Giles' translation of The Art of War. Perspectives, 26(4), 593-611. https://doi.org/10.1080/0907676X.2017.1401650

17. Naghmeh-Abbaspour, B. (2013). Domestication and Foreignization in Translation of Children's Literature. In New Literacies:Reconstructing Education and Language (pp. 62-72). Cambridge: Cambridge scholars.

18. Naghmeh-Abbaspour, B., Mahadi, T. S. T., \& Jamal, M. (2019). The impact of dominant ideology of target society on lexical choices of translation: the case study of the essential rumi. Humanities \& Social Sciences Reviews, 7(6), 1162-1171. https://doi.org/10.18510/hssr.2019.76166

19. Neveu, A. (2017). How Paratexts Influence the Reader's Experience of English Translations of La Fontaine's Fables. New Voices in Translation Studies, (16).

20. Nord, C. (2012). Paratranslation-a new paradigm or a re-invented wheel?. Perspectives, 20(4), $399-409$. https://doi.org/10.1080/0907676X.2012.726231

21. O'Sullivan, E. (2005). Comparative children's literature. Routledge.

22. Oittinen, R. (2002). Translating for children (Vol. 2150). Routledge. https://doi.org/10.4324/9780203902004

23. Oittinen, R. (2004). Change and Renewal: Translating the Visual in Picture Books. Change and Renewal in Children's Literature. Westport, London: Praeger, 171-181.

24. Oittinen, R. (2014). On the Ethics of Translating for Children. Children's literature in translation: challenges and strategies, 35 . 
25. Paprocka, N. (2018). Translating Picturebooks: Revoicing the Verbal, the Visual and the Aural for a Child Audience. RiittaOittinen, Anne Ketola and Melissa Garavini. https://doi.org/10.3366/ircl.2018.0276

26. Pantaleo, S. (2017). Paratexts in picturebooks. In The Routledge Companion to Picturebooks (pp. 38-48). Routledge. https://doi.org/10.4324/9781315722986-5

27. Pereira, N. (2008). Book illustration as (intersemiotic) translation: pictures translating words. Meta: journal des traducteurs/Meta: Translators' Journal, 53(1), 104-119. https://doi.org/10.7202/017977ar

28. Patron, S. (2007). The higher power of Lucky. Simon and Schuster.

29. Rose, G. (2016). Visual methodologies: An introduction to researching with visual materials. Sage.

30. Rovira-Esteva, S. (2016). The (mis) use of paratexts to (mis) represent the other: Chun Sue's Beijing Doll as a case study. Onomázein, (34), 187-208. https://doi.org/10.7764/onomazein.34.11

31. Stevenson, D. (2009). Umbrella Summer. Bulletin of the Center for Children's Books, 62(11), 445-445. https://doi.org/10.1353/bcc.0.1045

32. Shavit, Z. (1981). Translation of Children's Literature as a Function of its Position in the Literary Polysystem. Poetics today, 2(4), 171-179. https://doi.org/10.2307/1772495

33. Smart, B. (2002). Michel Foucault: critical assessments. Psychology Press.

34. Sonzogni, M. (2011). Re-Covered Rose. A Case Study in Book Cover Design as Intersemiotic Translation. Amsterdam. https://doi.org/10.1075/z.169

35. Tymoczko, M. (1999). Post-colonial writing and literary translation. Post-colonial translation: Theory and practice, 19-40.

36. Van Coillie, J. (2006). Character names in translation. A functional approach.

37. Wolf, M. (2002). Censorship as cultural blockage: Banned literature in the late Habsburg monarchy. TTR: traduction, terminologie, rédaction, 15(2), 45-61. https://doi.org/10.7202/007478ar 